\title{
EVALUATION OF RENAL EPITHELIAL CELL PROTEIN UNDER STRESS CONDITION
}

\author{
PRIYADARSHINI*, KANIKA JAIN, RAJEEV SOOD
}

Jaypee Institute of Information Technology, Noida, India Email: priya.juit@gmail.com

Received: 25 Jul 2016 Revised and Accepted: 09 Sep 2016

\begin{abstract}
Objective: Proteins are an important component of cells which are involved in various cellular functions. Different kind of stressing conditions has different responses in the components of the protein synthesis system. Super saturation condition in kidney environment leads to crystallization process. Crystals thus formed injure the surrounding cells and result in reactive oxygen species (ROS) formation. There might be some changes in the protein synthesis when the kidney cells enter in oxidative stress. In the present study, kidney cell lines were exposed to oxidative stress and their proteins were analyzed using Bradford analysis and SDS-PAGE.
\end{abstract}

Methods: Vero cells were obtained from NCCS Pune and cultured in DMEM (Dulbecco's Modified Eagle's Medium) and maintained in a humidified incubator at $37{ }^{\circ} \mathrm{C}$ with $5 \% \mathrm{CO}_{2}$. Calcium phosphate (CaP) crystals were prepared by the homogeneous system. After FTIR analysis crystals were used to injure Vero cell line. $\mathrm{H}_{2} \mathrm{O}_{2}$ was also used to injure the Vero cells. Intracellular protein was extracted from healthy cells and injured cells (with $\mathrm{CaP}$ crystals and $\mathrm{H}_{2} \mathrm{O}_{2}$ ). Ammonium sulfate precipitation method was used for the isolation of extracellular protein from the media of healthy and injured cells. Bradford method was used for the quantitative estimation of protein. Extracted proteins were analyzed by SDS-PAGE.

Results: Amount of intracellular and extracellular protein of normal cells was $4.84 \pm 0.004 \mu \mathrm{g} / \mathrm{ml}$. Intracellular protein of $\mathrm{CaP}$ injured and $\mathrm{H}_{2} \mathrm{O}_{2}$ injured cells were $10.59 \pm 0.003 \mu \mathrm{g} / \mathrm{ml}$ and $10.78 \pm 0.011 \mu \mathrm{g} / \mathrm{ml}$ respectively. While extracellular protein of injured cells was nearly $4 \mu \mathrm{g} / \mathrm{ml}$ Intracellular protein bands ranging from 14.3 to $97.4 \mathrm{kDa}$ was observed in healthy cells. Protein bands of $\sim 40 \mathrm{kDa}$ and $\sim 20 \mathrm{kDa}$ was absent in $\mathrm{H}_{2} \mathrm{O}_{2}$ and $\mathrm{CaP}$ injured intracellular protein extract. Two extracellular protein bands of $66 \mathrm{kDa}$ and $\sim 60 \mathrm{kDa}$ were present in injured cells and healthy cells.

Conclusion: When exposed to oxidative stress several proteins are oxidized decreasing the activity of many metabolic pathways. In the present study amount of intracellular protein increases when cells are injured with $\mathrm{CaP}$ or $\mathrm{H}_{2} \mathrm{O}_{2}$. While extracellular protein remains more or less same in both healthy and injured condition of cells. In SDS-PAGE analysis few bands were missing in the intracellular extract of injured cells. These results indicate that the amount of protein varies when cells are injured with $\mathrm{CaP}$ and $\mathrm{H}_{2} \mathrm{O}_{2}$.

Keywords: Oxidative stress, Kidney, Protein, Calcium phosphate, Crystal

(C) 2016 The Authors. Published by Innovare Academic Sciences Pvt Ltd. This is an open access article under the CC BY license (http://creativecommons.org/licenses/by/4. 0// DOI: http://dx.doi.org/10.22159/ijpps.2016v8i11.14310

\section{INTRODUCTION}

Kidney stone disease is a major public health concern that affects a significant fraction of the world population. Due to super saturation crystals are formed which serves as nidus for the growth of the crystal. Large crystals retain in kidney and forms kidney stones. Calcium phosphate is the first crystal that forms in the loop of Henle or in the distal part of the distal tubule [1-4]. Adhesion of these crystals to renal epithelial cells generates excess ROS, causing injury and inflammation [5]. Different kinds of stressing conditions might have different responses in the components of the protein synthesis system. Within the cell, several targets are oxidized decreasing the activity of many metabolic pathways including translation in both prokaryotic as well as eukaryotes. Part of this inhibition might be due to the oxidative inactivation of several enzymes involved in the metabolism of energy and amino acid synthesis both of which are essential for protein synthesis [6]

Oxidative stress leads to a cascade of events in a cell including the upregulation and down regulation of various proteins. Study of proteins during the injury of renal epithelial cells by crystals will help to understand the etiology of urolithiasis. Cellular protein profile of crystal injured renal epithelial cells have not been reported so far, therefore the current research attempts to identify the protein from healthy and injured African monkey renal epithelium (Vero cell line) through SDS-PAGE analysis. Protein quantity was determined by Bradford method. Protein bands of healthy and injured cells which appeared on the gel were compared.

Triton X and PMSF (phenyl methyl sulfonyl fluoride) were obtained from Sigma, DTT (Dithiothreitol) from CDH and DMEM from Himedia, India. All other chemicals were of analytical grade.
CaP crystals were prepared by mixing $5 \mathrm{mmol} \mathrm{CaCl}_{2}$ and $5 \mathrm{mmol}$ $\mathrm{KH}_{2} \mathrm{PO}_{4}$ with Tris buffer [pH 7.4] and distilled water. The mixture was incubated at $37{ }^{\circ} \mathrm{C}$ for $30 \mathrm{~min}$ and $\mathrm{CaP}$ crystals were harvested by centrifugation at $4000 \mathrm{rpm}$ for $15 \mathrm{~min}[7,8]$. Supernatant was discarded and crystals were washed twice in distilled water. The pellets were then dried and were analyzed by FTIR (Spectrum BX-II FTIR spectrophotometer, Perkin Elmer) and SEM (Zeiss EV040).

Renal epithelial cells derived from green African monkey (Vero Cells) were obtained from National Centre of Cell Sciences (NCCS, Pune). Cells were maintained as monolayers in Dulbecco's Modified Eagle's Medium (DMEM) with 10\% FBS and antibiotics streptomycin $(100 \mathrm{mg} / \mathrm{ml})$, penicillin $(60 \mathrm{mg} / \mathrm{ml})$, gentamycin $(100 \mathrm{mg} / \mathrm{ml})$ in 25 $\mathrm{cm}^{2}$ tissue culture flask and maintained in a humidified incubator at $37{ }^{\circ} \mathrm{C}$ with $5 \% \mathrm{CO}_{2}[9]$.

The cells were seeded in six-well plates, incubated at $37^{\circ} \mathrm{C}$ for $24 \mathrm{~h}$, with $5 \%$ carbon dioxide in a humidified incubator. Media were changed to serum-free culture media and the cells were incubated for $12 \mathrm{~h}$ for acclimatization purpose. The cells in control group were exposed to serum-free culture medium only, whereas the cells in injury group were injured separately with $0.3 \mathrm{mmol}$ hydrogen peroxide and with $10 \mu \mathrm{g} / \mathrm{ml}$ of CaP crystals [10]. After $24 \mathrm{~h}$ of incubation, intracellular proteins were extracted from cells and extracellular proteins were extracted from the culture media.

Proteins were extracted from the cells injured with $\mathrm{H}_{2} \mathrm{O}_{2}$ and cells injured with $\mathrm{CaP}$ crystals as well as healthy cells and from the culture media in which they were grown. Protein extraction buffer (1M HEPES Buffer, $100 \%$ Glycerol, $5 \mathrm{M} \mathrm{NaCl}, 1 \mathrm{M} \mathrm{MgCl}_{2}, 500 \mathrm{mmol}$ EDTA, 100\% Triton-X 100, 1M PMSF, 1M DTT, 1M Protein Inhibitor 
cocktail) was used for intracellular protein of injured and control group. After trypsinization, cells of each group were suspended in the extraction buffer and incubated in ice for $1 \mathrm{hr}$ with intermittent tapping at an interval of $10 \mathrm{~min}$. The suspensions were centrifuged at $10000 \mathrm{rpm}$ for $18 \mathrm{~min}$ at $4{ }^{\circ} \mathrm{C}$ and the extracted protein present in the supernatant was aliquoted immediately into labelled microfuge tubes and stored at $-80^{\circ} \mathrm{C}$.

Extracellular proteins present in the serum-free media of each group were extracted using ammonium sulfate precipitation method. The proteins were quantitated through Bradford method [11].

For SDS-PAGE each extracted protein sample was reconstituted with loading buffer containing $\beta$-mercapto ethanol. Samples were heated to $95{ }^{\circ} \mathrm{C}$ for $5 \mathrm{~min}$ and were submitted to electrophoresis using $5 \%$ stacking and $10 \%$ separating gels. Medium range molecular weight markers were used as standards. Protein bands were stained with silver staining.

FTIR graph has peaked at a wave number of $1000-1100 / \mathrm{cm}, 3600-$ $3900 / \mathrm{cm}, 1460-1700 / \mathrm{cm}$ which correspond to phosphate, hydroxide and carbonate respectively. These peaks indicated the presence of CaP crystals. Scanning electron micrograph and FTIR analysis of CaP crystals are shown in fig. 1.
The protein content of total cellular extract of healthy cells (4.84 $\mu \mathrm{g} / \mathrm{ml}$ ) was less as compared to the injured group. CaP crystals injured cells was $10.59 \mu \mathrm{g} / \mathrm{ml}$ and $\mathrm{H} 202$ injured cells was 10.78 $\mu \mathrm{g} / \mathrm{ml}$. The protein content of culture media extracted protein of healthy cells $(4.94 \mu \mathrm{g} / \mathrm{ml})$, CaP injured cells $(4.31 \mu \mathrm{g} / \mathrm{ml}), \mathrm{H} 2 \mathrm{O} 2$ injured cells $(3.87 \mu \mathrm{g} / \mathrm{ml})$ had less amount of protein.

The total cellular and media protein extract of healthy and injured cells presented different profiles of separate protein bands on the gel after silver staining (fig. 3 and 4).

SDS-PAGE depicts that bands of molecular weights such as $97.4 \mathrm{kDa}$, approximately $70 \mathrm{kDa}, 66 \mathrm{kDa}$, multiple bands between $66 \mathrm{kDa}$ and $43 \mathrm{kDa}, 29 \mathrm{kDa}, 14.3 \mathrm{kDa}$ were observed in the case of total cellular protein extract of healthy and injured cells. In the case of CaP and $\mathrm{H} 2 \mathrm{O} 2$ injured cell extract, bands of molecular weights of $39 \mathrm{kDa}$, $37 \mathrm{kDa}, 36 \mathrm{kDa}$ and $35 \mathrm{kDa}$ were missing (fig. 3).

Multiple bands of molecular weights ranging from $97.4 \mathrm{kDa}$ to $14.3 \mathrm{kDa}$ were observed in the case of healthy cells culture media protein extract obtained from cells grown in complete media. Whereas, in case of $\mathrm{CaP}$ and $\mathrm{H}_{2} \mathrm{O}_{2}$ injured cell culture media extract as well as an extract obtained from cells grown in incomplete

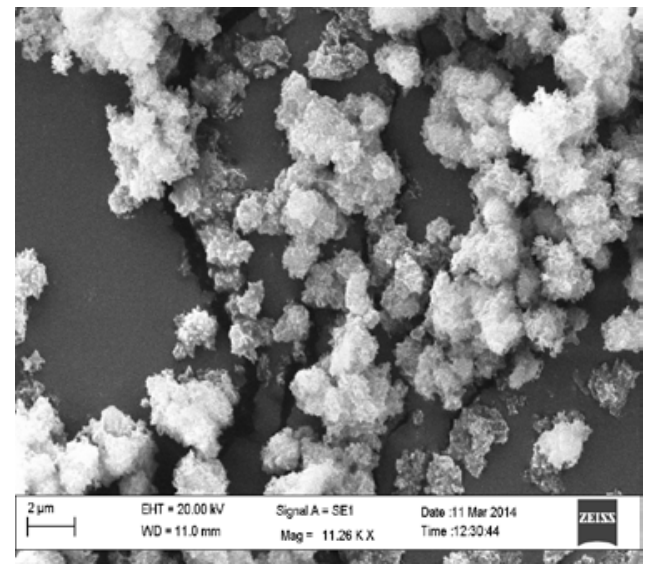

A

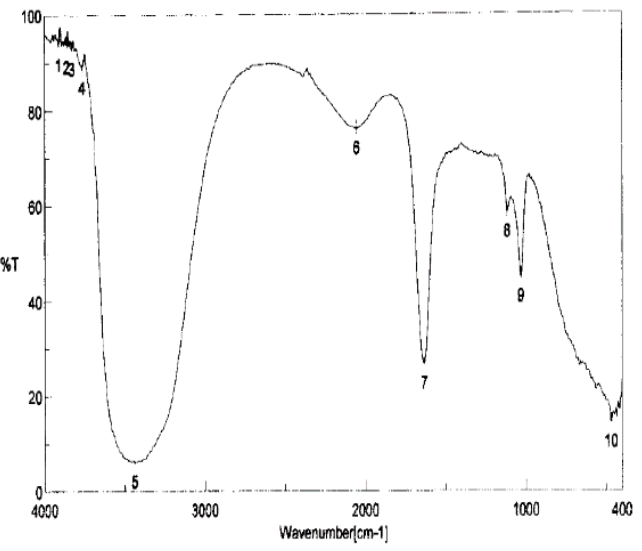

B

Fig. 1: Morphology and composition analysis of calcium phosphate crystals. A. Scanning electron microscopy (scale bar $2 \mu \mathrm{m}$ ) B. Fourier transform infrared spectroscopy

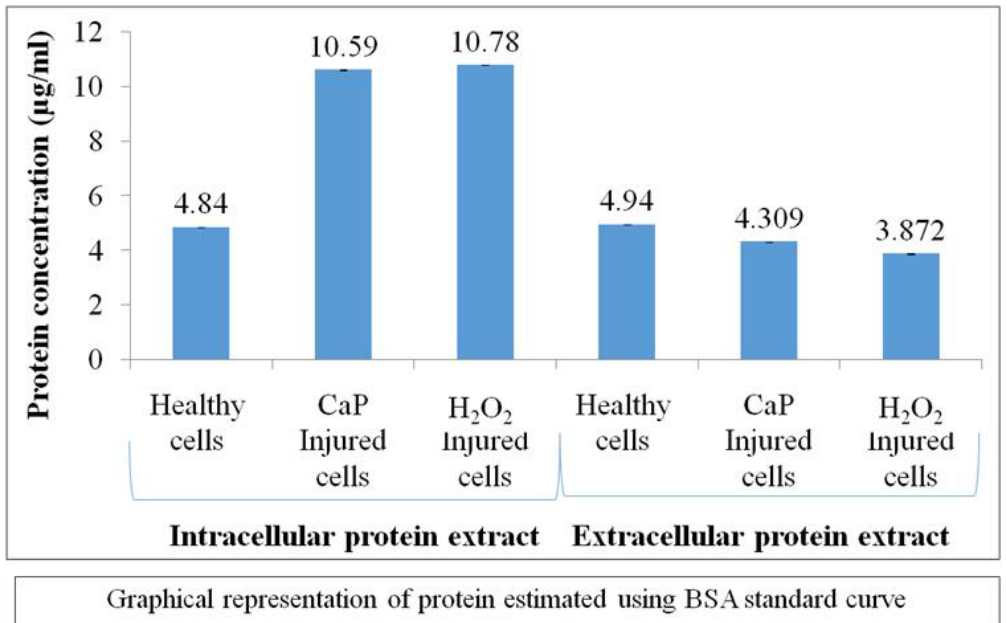

Fig. 2: Protein concentration present in different samples

Whereas, in the case of $\mathrm{CaP}$ and $\mathrm{H}_{2} \mathrm{O}_{2}$ injured cell culture media extract as well as an extract obtained from cells grown in incomplete media, two bands of molecular weight $66 \mathrm{kDa}$ and approximately $60 \mathrm{kDa}$ were observed as shown in fig. 4 . 


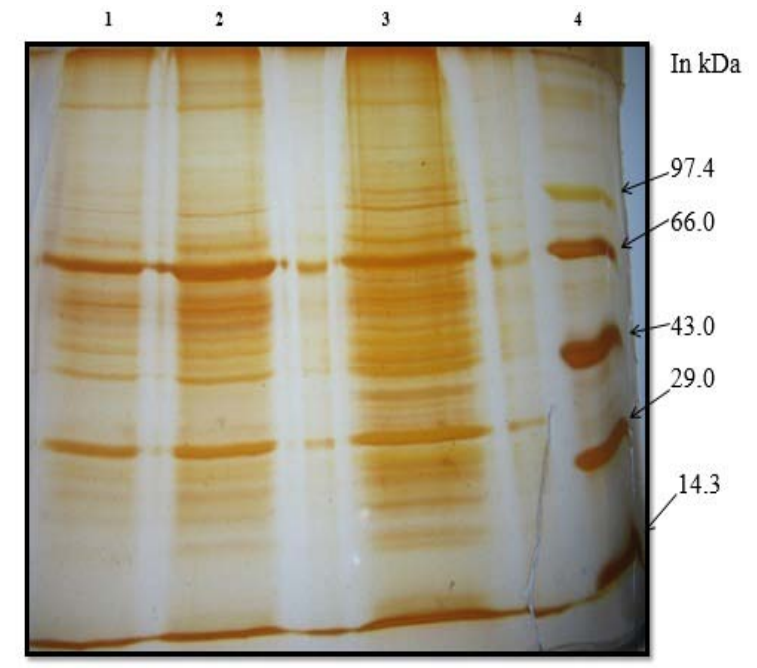

Fig. 3: SDS-PAGE analysis of Vero cell extract. Lane 1 CaP crystal injured cell extract, Lane 2- $\mathrm{H}_{2} \mathrm{O}_{2}$ injured cell extract, Lane 3Normal cell extract, Lane 4-Medium range protein marker. In the injured group various protein bands are missing which are present in healthy cell extract

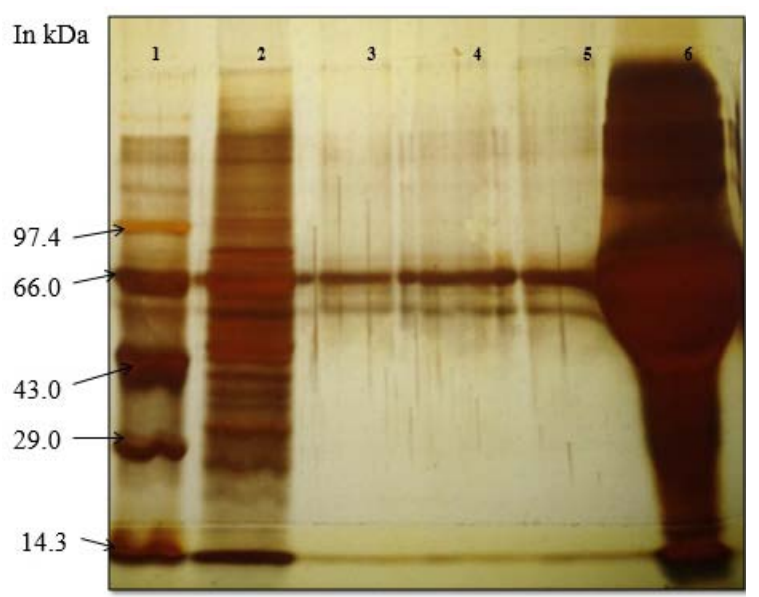

Fig. 4: SDS-PAGE analysis of cells culture media protein extract. Lane 1-Medium range protein marker, Lane 2-Extracellular protein of healthy cells grown $(24 \mathrm{~h})$ in complete media, Lane 3$\mathrm{H}_{2} \mathrm{O}_{2}$ injured cell supernatant extract, Lane 4-CaP crystal injured cell supernatant extract, Lane 5-Extracellular protein of healthy cells grown $(24 \mathrm{~h})$ in incomplete media, Lane 6-Fetal Bovine Serum (FBS). Two bands of 60 and $\sim 66 \mathrm{kDa}$ were observed in healthy and injured group in cell culture media extract

One of the major aspects in stone formation is reactive oxygen species (ROS), when generated uncontrollably they provide the surface for attachment of crystals, leading to the formation of stones [1-3]. Injury of the renal epithelial cells results in alteration of various cellular activities including protein synthesis. Proteins are a vital part of the organism and participate in almost every process in the cell. Interference in its synthesis process will lead to upset cellular fitness, cause disease phenotypes. In the present study, we have studied the protein of healthy and injured renal epithelial cells of Vero cell line.

The amount of cellular protein was increased from healthy cells $(4.84 \mu \mathrm{g} / \mathrm{ml})$ to injured cells $(\sim 10.5 \mu \mathrm{g} / \mathrm{ml})$ whereas in extracellular protein there was not much difference in the amount of protein secreted.

In our experiment, we observed that in the intracellular protein of injured group several protein bands of approximately $39 \mathrm{kDa}, 37 \mathrm{kDa}$,
$36 \mathrm{kDa}$ and $35 \mathrm{kDa}$ molecular weight were missing, while they were present in the healthy group. Protein bands of $97.4 \mathrm{kDa}$ and $70 \mathrm{kDa}$ were present in both healthy and injured cells [12].

African green monkey renal epithelial cells release a glycoprotein $39 \mathrm{kDa}$ protein that blocks adhesion of COM crystals to the apical cell surface. CAI (crystal adhesion inhibitor) is a constituent of human urine; it is likely that this glycoprotein is present in sufficient quantities in the tubular fluid in vivo to coat crystals and prevent their adhesion to renal epithelial cells [13]. The absence of this protein might lead to the adhesion of crystals to the injured cells and growth thereof.

$37 \mathrm{kDa}$ proteins from MDCK (Madin-Darby canine kidney) cell line were reported as laminin binding protein related to the $37 / 67 \mathrm{kDa}$ laminin receptor family involved in cell attachment, spreading and polarization [14].

$35 \mathrm{kDa}$ and $38 \mathrm{kDa}$ protein are also reported as glycosylphosphatidylinositol-anchored proteins from renal epithelial cells of MDCK cell line [15]. These proteins were restricted to the apical domain of the plasma membrane indicating their role in polarization of the epithelial cells. Another $35 \mathrm{kDa}$ protein is reported to be a splicing factor involved in the removal of introns from strings of messenger RNA [16].

In summary, we demonstrated that amount of proteins in Vero epithelial cells vary when they are injured with CaP crystals or $\mathrm{H}_{2} \mathrm{O}_{2}$ while the amount of extracellular proteins remains same. Proteins which were absent in the injured group were found to be significant in crystal and epithelial cell interaction, cell attachment, in the polarization of cells and in splicing activity. These results suggest that injury of epithelial cells either with crystals or $\mathrm{H}_{2} \mathrm{O}_{2}$ is interfering with protein synthesizing mechanism. Future studies will help us to identify and characterize these proteins and their role in urolithiasis.

\section{ACKNOWLEDGEMENT}

We express our gratitude to the AIRF, JNU, Delhi for SEM analysis and Department of Physics and Materials Science and Engineering, JIIT, Noida for FTIR analysis of the sample. We would also like to thank Jaypee Institute of Information Technology, Noida for providing funds for carrying out this research work.

\section{CONFLICTS OF INTERESTS}

Declared none

\section{REFERENCES}

1. Luptak J, Bek-Jensen H, Fornander AM. Crystallization of calcium oxalate and calcium phosphate of supersaturation levels corresponding to those in different parts of the nephron. Scanning Microsc 1994;8:47-62.

2. Tiselius HG. Solution chemistry of supersaturation. In kidney stones-medical and Surgical Management. ed. FL Coe, MJ Flavus, CYC Pak, JH Parks, GM Preminger. Philadelphia: Lippincott-Raven Publishers; 1996. p. 33-64.

3. Asplin JR, Mandel NS, Coe FL. Evidence for calcium phosphate supersaturation in the loop of Henle. Am J Physiol 1996;270:F604-13.

4. Höjgaard I, Tiselius HG. Crystallization in the nephron. Urol Res 1999;27:397-403.

5. Khan SR. Reactive oxygen species, inflammation and calcium oxalate nephrolithiasis. Transl Androl Urol 2014;3:256-76.

6. Katz A, Orellana 0. Protein Synthesis and the Stress Response, CellFree Protein Synthesis, Prof. Manish Biyani. Ed. InTech; 2012.

7. Kabra SG, Kabra V, Banerji P, Jain LK, Bhargava A, Chaturvedi RP. In vitro calculogenesis: methods to develop concretions of desired chemical composition. Indian J Exp Biol 1978;16:212-7.

8. Pathak P, Singh SK, Tandon C. Effect of Biomolecules from the human renal matrix of calcium oxalate monohydrate $(\mathrm{CaOx})$ stones on in vitro calcium phosphate crystallization. Int Brazilian J Urol 2010;36:621-8.

9. Priyadarshini, Jain K. Cytoprotective effect of Ocimum extract on injured renal epithelial cells. Int J Pharmacol Pharm Sci 2015;7:15-8. 
10. Ouyang JM, Yao XQ, Tan J, Wang FX. Renal epithelial cell injury and its promoting role in the formation of calcium oxalate monohydrate. JBIC J Biol Inorg Chem 2011;16:405-16.

11. Bradford MM. A rapid and sensitive for the quantitation of microgram quantities of protein utilizing the principle of protein-dye binding. Anal Biochem 1976;72:248-54.

12. Singh A, Puri D, Kumari B, Singh SK. Heat shock proteins: knowledge so far and its future prospects. Asian J Pharm Clin Res 2016;9:17-24.

13. Kumar V, Yu S, Farell G, Toback FG, Lieske JC. Renal epithelial cells constitutively produce a protein that blocks adhesion of crystals to their surface. Am J Physiol Renal Physiol 2004;287:F373-83.

14. Salas PJ, Ponce MI, Brignoni M, Rodríguez ML. Attachment of madin-darby canine kidney cells to extracellular matrix: the role of a laminin-binding protein related to the $37 / 67 \mathrm{kDa}$ laminin receptor in the development of plasma membrane polarization. Biol Cell 1992;75:197-210.

15. Lisanti MP, Sargiacomo M, Greave L, Saltiel AR, Boulan ER Polarized apical distribution of glycosyl-phosphatidyl inositol anchored proteins in a renal epithelial cell line. Proc Natl Acad Sci USA 1988;85:9557-61.

16. Cavaloc Y, Popielarz M, Fuchs JP, Gattoni R, Stvenin J. Characterization and cloning of the human splicing factor 9G8: a novel $35 \mathrm{kDa}$ factor of the serine/arginine protein family. EMBO J 1994;13:2639-49.

\section{How to cite this article}

- $\quad$ Priyadarshini, Kanika Jain, Rajeev Sood. Evaluation OF renal epithelial cell protein under stress condition. Int J Pharm Pharm Sci 2016;8(11):337-340. 